Tropical Journal of Pharmaceutical Research January 2017; 16 (1): 135-140

ISSN: $1596-5996$ (print); 1596-9827 (electronic)

(C) Pharmacotherapy Group, Faculty of Pharmacy, University of Benin, Benin City, 300001 Nigeria.

All rights reserved.

Available online at http://www.tjpr.org

Original Research Article

http://dx.doi.org/10.4314/tjpr.v16i1.17

\title{
Effect of acetone extract of Rumex japonicas Houtt on hydrogen peroxide-induced apoptosis in rat myocardial cells
}

\author{
Xiao-Bo Zhou ${ }^{1}$, Kai-Wu Cao ${ }^{1}$, Ling-Kun Song ${ }^{2}$, Shuang-Qing Kou ${ }^{1}$, Shen-Cheng \\ $\mathbf{Q u}^{1}$, Cong Wang ${ }^{1}$, Ying Yu${ }^{1}$, Yu Liu ${ }^{1}$, Peng-Ying $\mathbf{L i}^{1}$ and Run-Peng Lu ${ }^{3 *}$ \\ ${ }^{1}$ Cardiovascular Department, Dongli Hospital, No. 245 Jintang Road, Tianjin 300300, ${ }^{2}$ Aid Center of Public Health Medicine, \\ No. 109 Baoyu Road, Chongqing 400000, ${ }^{3}$ Vascular Surgery, Dongli Hospital, No. 245 Jintang Road, Tianjin 300300, PR China \\ ${ }^{*}$ For correspondence: Email: lurpdlhsp@163.com
}

Received: 9 September 2016

Revised accepted: 14 December 2016

\begin{abstract}
Purpose: To investigate the protective effect of the acetone extract of Rumex japonicas Houtt. (AER) on rat myocardial cells.

Methods: R. japonicas was extracted with $75 \%$ aqueous ethanol by reflux to afford total extract (TER). $T E R$ was suspended in water and then extracted with acetone to afford acetone fraction of $R$. japonicas (AER). High performance liquid chromatography (HPLC) combined with standard substances was carried out to analyze the major constituents of AER. Apoptosis in myocardial H9c2 cell line was induced by $\mathrm{H}_{2} \mathrm{O}_{2}(100 \mu \mathrm{mo} / \mathrm{L})$. The cells were treated with $\mathrm{AER}(50,100$ and $200 \mu \mathrm{g} / \mathrm{mL}$, and cell viability was evaluated by the 3- (4,5-dimethyl-2-thiazolyl)-2,5-diphenyl-2-H-tetrazolium bromide (MTT) assay, while oxidative stress level in $\mathrm{H} 9 \mathrm{c} 2$ cells was evaluated by determining levels of lactate dehydrogenase ( $L D H)$, malondialdehyde (MDA), creatinine kinase (CK), superoxide dismutase (SOD), and catalase (CAT). Furthermore, apoptotic proteins (caspase-3, Bax and $\mathrm{BCl}-2$ ) in $\mathrm{H} 9 \mathrm{c} 2$ cells were analyzed by using western blot assay.

Results: Results revealed that the main components of AER are aloe-emodin, rhein, emodin, chrysophanol and physcion. AER (50,100 and $200 \mu \mathrm{g} / \mathrm{mL}$ ) inhibited the cell viability reduction of the H9c2 cells induced by $\mathrm{H}_{2} \mathrm{O}_{2}(p<0.05, p<0.01, p<0.01$, respectively). AER $(50,100$ and $200 \mu \mathrm{g} / \mathrm{mL})$ decreased LDH and CK contents of H9c2 cells $(p<0.01)$. The levels of SOD $(p<0.01)$ and CAT $(p<$ 0.01) were increased by AER treatments (100 and $200 \mu \mathrm{g} / \mathrm{mL})$; in addition, AER (50, 100 and 200 $\mu \mathrm{g} / \mathrm{mL})$ decreased MDA levels $(p<0.01)$. Besides, the present results also revealed that AER could down-regulate caspase-3 and Bax, but up-regulated $\mathrm{Bcl}-2$.

Conclusion: $A E R$ alleviates apoptosis induced by $\mathrm{H}_{2} \mathrm{O}_{2}$ in myocardial $\mathrm{H} 9 \mathrm{c} 2$ cells via inhibition of oxidative stress and mitochondria-mediated apoptosis. This finding suggests that AER can potentially be developed for the treatment of myocardial apoptosis.
\end{abstract}

Keywords: Rumex japonicas Houtt., Myocardial cells, Apoptosis, H9c2 cell, Oxidative stress

Tropical Journal of Pharmaceutical Research is indexed by Science Citation Index (SciSearch), Scopus, International Pharmaceutical Abstract, Chemical Abstracts, Embase, Index Copernicus, EBSCO, African Index Medicus, JournalSeek, Journal Citation Reports/Science Edition, Directory of Open Access Journals (DOAJ), African Journal Online, Bioline International, Open-J-Gate and Pharmacy Abstracts

\section{INTRODUCTION}

Plants in the Rumex genus belong to the family of Polygonaceae, and are annual or perennial herbs distributed throughout the world [1,2]. In
Chinese folk medicine, plants in this genus have been used for treating various diseases from ancient times, and have medicinal functions of promoting blood circulation, removing blood stasis, detoxication, etc [2,3]. In addition, 
previous investigations have indicated that plants in Rumex genus contain large quantities of anthraquinone derivatives $[2,4,5]$.

Rumex japonicus Houtt is widely distributed throughout China [6,7]. In China, the whole herb of $R$. japonicus has been traditionally used as an important traditional medicine for treating inflammatory diseases, tumors, infections, and constipation, etc. It is reported that $R$. japonicus contains a large number of anthraquinones, flavones and oxanthrones, etc $[8,9]$. Previous works revealed that natural extracts or monomeric compounds derived from the family of Polygonaceae are beneficial for protection of cardiac functions in many heart diseases $[2,10,11]$. In Chinese folk medicine, the whole herb of $R$. japonicas is commonly used as an ingredient of prescriptions for treating heart diseases based on the function of promoting blood circulation for removing blood stasis [2,12]. To the best of our knowledge, no experimental work on the myocardial protective effect of $R$. japonicas has been carried out. Thus, this study is designed to investigate the protective effects of the acetone extracts of $R$. japonicas (AER) on myocardial cells using a $\mathrm{H}_{2} \mathrm{O}_{2}$-induced myocardial apoptosis $\mathrm{H} 9 \mathrm{c} 2$ cell model.

\section{EXPERIMENTAL}

\section{Cell culture}

Rat ventricular cardiomyoblast $\mathrm{H} 9 \mathrm{c} 2$ cell line was obtained from the American Type Culture Collection (ATCC, Manassas, VA, USA). The cells were cultured in the Dulbecco's modified Eagle's medium (DMEM) containing $10 \%$ fetal bovine serum (FBS) at $37{ }^{\circ} \mathrm{C}$ in an incubator (Sanyo, Japan) in $5 \% \mathrm{CO}_{2} / 95 \%$ air.

\section{Chemicals}

The DMEM media and FBS were purchased from Gibco Co. (Grand Island, NY, USA). Methylthiazdyldiphenyl-tetrazolium bromide (MTT), methanol $(\mathrm{MeOH})$ (chromatographically pure, $\mathrm{CP}$ ), $\mathrm{H}_{2} \mathrm{O}_{2}$ and dimethyl sulfoxide (DMSO) were purchased from the Sigma Ltd. Co. (St. Louis, MO, USA). Assay kits for Lactate dehydrogenase (LDH), malondialdehyde (MDA), superoxide dismutase (SOD) assay kit, creatinine kinase (CK) and catalase (CAT) were purchased from the Nanjing Jiancheng Biotech. Co. (Nanjing, China). IP cell lysis buffer, BCA protein assay kit, and Caspase-3, Bax and $\mathrm{Bcl}-2$ primary antibodies were purchased from the Beyotime Co. (Haimen, China). Standard references including aloe-emodin, rhein, emodin, chrysophanol and physcion was obtained from the National Institute for the Control of Pharmaceutical and Biological Products (Beijing, China).

\section{Plant material and AER preparation}

AER was prepared according to the method described previously with minor modifications [13]. The dried whole herb of $R$. japonicas (purchased from the Tongrentang traditional Chinese medicine drug store, Tianjing, China) was powdered and extracted with $75 \%$ aqueous ethanol by reflux ( 3 times, each for $2 \mathrm{~h}$ ). The filtrates were combined and then evaporated at $50{ }^{\circ} \mathrm{C}$ in vacuo to afford total extract of $R$. japonicas (TER). Subsequently, TER was suspended in water and extracted with acetone using a $10 \mathrm{~L}$ separating funnel, and the acetone extract evaporated at $50^{\circ} \mathrm{C}$ in vacuo using a 10 L rotary evaporator (RE-5210, Shyarong Co., Shanghai, China) to afford the acetone extract of $R$. japonicas (AER).

\section{HPLC analysis of AER}

Methanol $(\mathrm{MeOH})$ was used to dissolve the AER to obtain appropriate concentration for high performance liquid chromatography (HPLC) assays. Chemical composition analysis of AER was carried out with an Agilent Technologies 1200 system (Palo Alto, CA, USA), and performed with a Venusil XBP- $\mathrm{C}_{18}$ column (4.6 $\mathrm{mm} \times 250 \mathrm{~mm}, 5 \mu \mathrm{m}$ ). The mobile phase for HPLC assay comprised of of $\mathrm{MeOH}-0.1 \%$ phosphoric acid aqueous solution (80:20). The injection volume of sample was $10 \mu \mathrm{L}$, and flow rate was set at $1 \mathrm{~mL} / \mathrm{min}$. The column temperature was set at $25^{\circ} \mathrm{C}$, and the detection wavelength was $254 \mathrm{~nm}$.

\section{MTT assay}

H9c2 cells $\left(5 \times 10^{4} / 200 \mu \mathrm{L}\right)$ were cultured in 96well plates, and then cells were treated with AER $(50,100$ and $200 \mu \mathrm{g} / \mathrm{mL}$ ) with the presence of $\mathrm{H}_{2} \mathrm{O}_{2}(100 \mu \mathrm{mo1} / \mathrm{L})$ in the following day [14]. After $24 \mathrm{~h}$ treatment, MTT assay was carried out according to the previous report [15] and absorbance (A) was detected at $570 \mathrm{~nm}$ using a 96-well plate reader (BioTek Instruments, Inc, Burlington, VT, USA). Cell viability (C) was determined as in Eq 1.

$C(\%)=(\mathrm{At} / \mathrm{Ac}) 100$

where At and Ac are the absorbance of treated and control samples, respectively. Each experiment was carried out in triplicate. 
Determination of LDH, CK, SOD, CAT and MDA in H9c2 cells

After $24 \mathrm{~h}$ treatment, the H9c2 cells' supernatants were collected to determine LDH and CK contents using commercial kits according to manufacturers' instructions. In addition, the total cell proteins of $\mathrm{H} 9 \mathrm{c} 2$ cells were extracted with IP cell lysis buffer, and protein concentration was analyzed using a BCA protein assay kit. Subsequently, contents of SOD, CAT and MDA were also measured using commercial kits following manufacturers' instructions.

\section{Western blot analysis}

$\mathrm{H} 9 \mathrm{c} 2$ cells were treated with AER $(200 \mu \mathrm{g} / \mathrm{mL})$ for $24 \mathrm{~h}$. Then, total proteins were extracted with IP cell lysis buffer, and protein concentration was determined using the BCA protein assay kit. Subsequently, a total of $35 \mu \mathrm{g}$ proteins were separated by sodium dodecyl sulfatepolyacrylamide gel electrophoresis (SDS-PAGE, $12 \%$ ), and then transferred to PVDF membranes (Boston, MA, USA). PVDF membranes were blocked with $5 \%$ fat-free milk, and subsequently incubated with primary antibodies of caspase-3, $\mathrm{Bax}$ and $\mathrm{Bcl}-2$, respectively. The protein bands were detected using HRP-conjugated secondary antibodies, and were visualized by the enhanced chemiluminescence reagent (Thermo Fisher Scientific, Shanghai, China). Thereafter, protein bands were quantitated using a Bio-Rad Chemi Doc XRS gel imaging system (Hercules, CA, USA).

\section{Statistical analysis}

Data are expressed as mean \pm standard deviation $(S D, n=3)$. Statistical analysis was performed by one-way ANOVA using SPSS software (SPSS for Windows 15.0, SPSS Inc, USA). $P<0.05$ was considered statistically significant.

\section{RESULTS}

\section{HPLC chromatograms}

As shown in Figure 1, over 10 peaks were detected within $45 \mathrm{~min}$ in the chromatogram map, among which 5 main compounds were identified by comparison with standard references. These 5 compounds were all anthraquinones and identified as aloe-emodin (1), rhein (2), emodin (3), chrysophanol (4) and physcion (5), respectively.

\section{Cell viability}

The present results (Figure 2) showed that after $\mathrm{H}_{2} \mathrm{O}_{2}$ induction $(100 \mu \mathrm{mo1} / \mathrm{L})$, cell viability of H9c2 cells (Control group) reduced sharply $(p<$ 0.01 ), compared to normal $\mathrm{H} 9 \mathrm{c} 2$ cells. Interestingly, AER treatments $(50,100$ and 200 $\mu \mathrm{g} / \mathrm{mL}$ ) significantly inhibited the $\mathrm{H}_{2} \mathrm{O}_{2}$ induced cell viability reduction in $\mathrm{H} 9 \mathrm{c} 2$ cells $(p<0.05, p<$ $0.01, p<0.01$, respectively), compared to control group. These results indicated that AER could enhance the cell viability of the $\mathrm{H}_{2} \mathrm{O}_{2}$ stimulated myocardial cell.

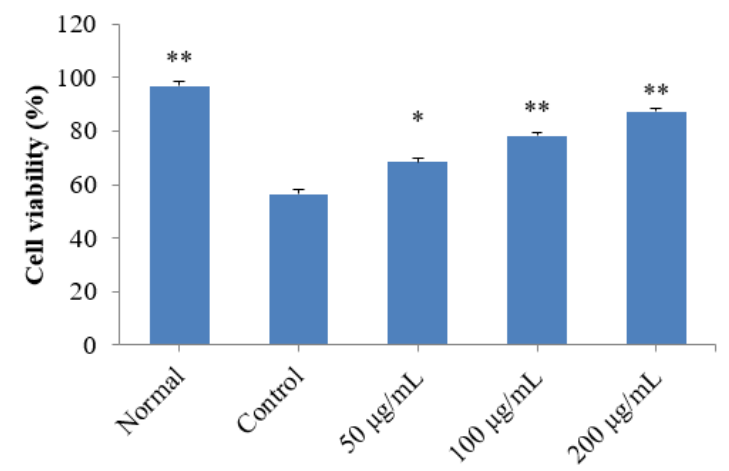

Figure 2: Effect of AER on cell viability of $\mathrm{H}_{2} \mathrm{O}_{2}$ stimulated $\mathrm{H} 9 \mathrm{c} 2$ cells. Data are presented as mean \pm SD $(\mathrm{n}=4) ;{ }^{*} p<0.05,{ }^{* *} p<0.01$, compared to control group $\left(\mathrm{H}_{2} \mathrm{O}_{2}\right.$ induction).

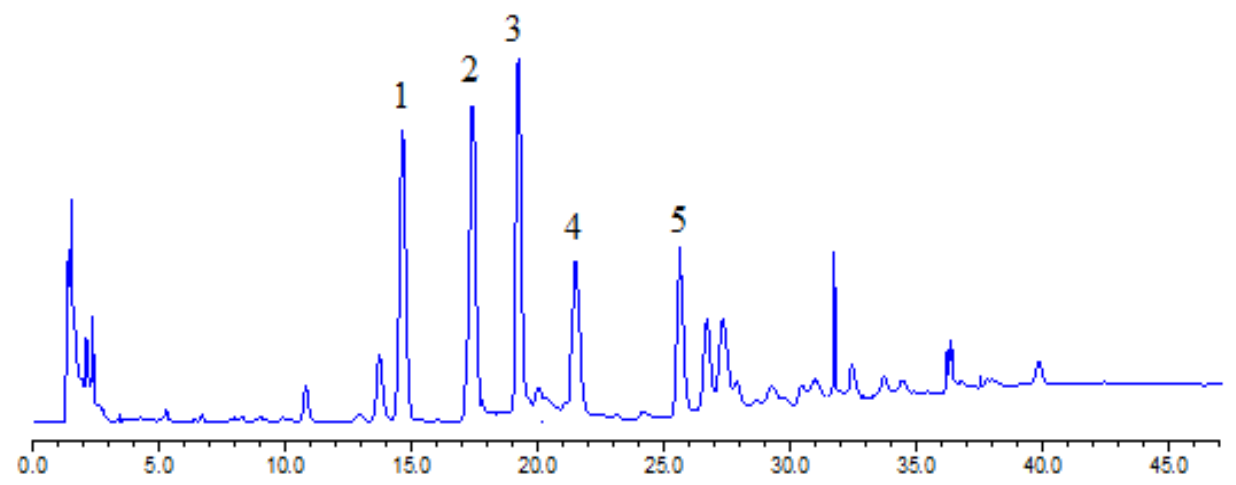

Figure 1: HPLC analysis of acetone extract isolated from $R$. japonicas. 1-5 represented the aloeemodin (1), rhein (2), emodin (3), chrysophanol (4) and physcion (5), respectively 


\section{LDH and CK contents}

As shown in Figure 3, following $\mathrm{H}_{2} \mathrm{O}_{2}$ stimulation, the contents of LDH and CK in H9c2 cells significantly increased $(p<0.01)$, compared to normal cells. After treatment with AER at concentrations of 50,100 and $200 \mu \mathrm{g} / \mathrm{mL}$, both the contents of LDH and CK significantly decreased $(p<0.01)$, compared to control group. These results indicate that AER alleviated leakages of CK and LDH from cytoplasm due to $\mathrm{H}_{2} \mathrm{O}_{2}$-induced cell membrane damage.

\section{SOD, CAT and MDA levels}

Levels of SOD, CAT and MDA in H9c2 cells were represented in Fig 4. After stimulation with $\mathrm{H}_{2} \mathrm{O}_{2}$, SOD and CAT levels in $\mathrm{H} 9 \mathrm{c} 2$ cells sharply decreased $(p<0.01)$, whereas the MDA content significantly increased $(p<0.01)$, compared to normal H9c2 cells. Interestingly, the levels of
SOD and CAT in H9c2 cells were significantly increased by treating AER (100 and $200 \mu \mathrm{g} / \mathrm{mL}$, $p<0.01$ ), compared to control group. In addition, the levels of MDA in AER (50, 100 and 200 $\mu \mathrm{g} / \mathrm{mL})$ treated group decreased significantly $(p<$ $0.01, p<0.01, p<0.01$ ), compared to control group.

\section{Apoptosis}

Apoptotic proteins' expressions (including caspase-3, Bcl-2 and Bax) were determined by western blot assays. Compared to normal H9c2 cells, after treatment with $\mathrm{H}_{2} \mathrm{O}_{2}$, expressions of caspase- 3 and Bax up-regulated, whereas the Bcl-2 expression down-regulated. However, expressions of caspase- 3 and Bax downregulated after treatment with AER $(200 \mu \mathrm{g} / \mathrm{mL})$, whereas the $\mathrm{Bcl}-2$ expression up-regulated, compared to control group.

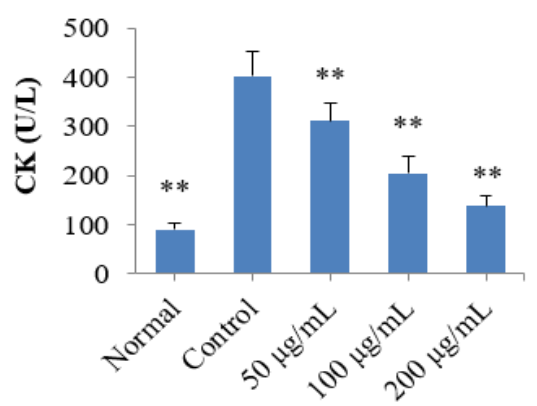

Figure 3: Effect of AER on contents of $\mathrm{LDH}$ and $\mathrm{CK}$ in $\mathrm{H}_{2} \mathrm{O}_{2}$ stimulated $\mathrm{H} 9 \mathrm{c} 2$ cells. Data are presented as mean $\pm \mathrm{SD}(\mathrm{n}=4) ;{ }^{*} p<0.05,{ }^{* *} p<0.01$, compared to control group $\left(\mathrm{H}_{2} \mathrm{O}_{2}\right.$ induction)
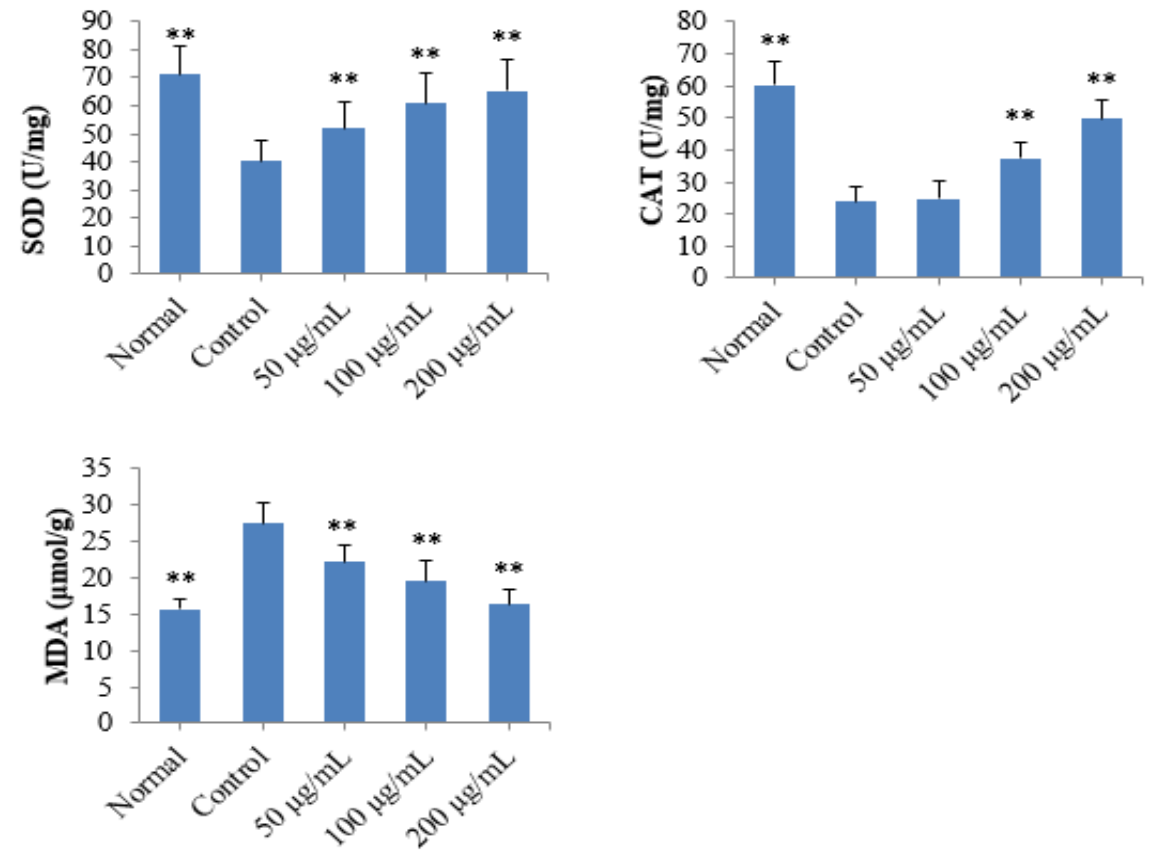

Figure 4: Effect of AER on contents of SOD, CAT and MDA in $\mathrm{H}_{2} \mathrm{O}_{2}$ stimulated $\mathrm{H} 9 \mathrm{c} 2$ cells. Data are presented as mean $\pm \mathrm{SD}(\mathrm{n}=4) ;{ }^{* *} p<0.01$, compared to control group $\left(\mathrm{H}_{2} \mathrm{O}_{2}\right.$ induction). 


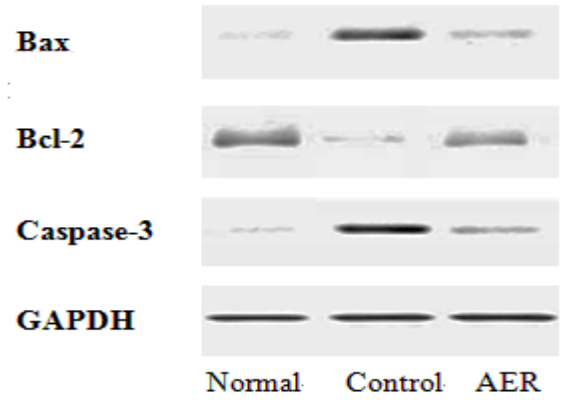

Figure 5: Effect of $A E R$ on protein expressions of Caspase-3, Bcl-2 and $\mathrm{Bax}$ in $\mathrm{H}_{2} \mathrm{O}_{2}$ stimulated H9c2 cells

\section{DISCUSSION}

Currently, cardiac diseases have become one of the leading causes of death worldwide, and the prevalence of cardiac diseases are growing rapidly [16]. In addition, ischemic coronary heart diseases, such as myocardial infarction, could result in myocardial apoptosis, leading to cardiac failure $[16,17]$. Therefore, inhibiting myocardial apoptosis is beneficial for treating ischemic coronary heart diseases.

The myocardial cell function is dependent on $\mathrm{O}_{2}$ consumption by mitochondria and electron transport chain $[18,19]$. Previous reports indicated that myocardial ischemia is mainly caused by imbalance of demand and supply of oxygen to heart $[14,20]$. Furthermore, increasing researches have demonstrated that oxidative stress is the crucial cause of pathogenesis of myocardial apoptosis [21]. Oxidative stress could result in over-produced oxygen free radical (ROS) which could damage cell membrane, enzymes, and electron transport chain, inducing cell apoptosis. According to previous investigations, $\mathrm{H}_{2} \mathrm{O}_{2}$ induced myocardial apoptosis $\mathrm{H} 9 \mathrm{c} 2$ cell model is commonly used to investigate pathological process and molecular mechanism of myocardial ischemia injury $[20,22]$. The results demonstrate that $A E R$ can alleviate the myocardial apoptosis induced by $\mathrm{H}_{2} \mathrm{O}_{2}$; furthermore, AER can also alleviate the leakages of $\mathrm{CK}$ and $\mathrm{LDH}$ from the cytoplasm due to $\mathrm{H}_{2} \mathrm{O}_{2}$ induced cell membrane damage. In oxidative stress, MDA is a major end-product of lipid peroxidation, and is considered as an indicator of tissue damage [23]. In contrast, GAT and SOD, the crucial anti-oxidative enzymes, are considered as antioxidant defense system in body which plays crucial roles in suppressing oxidative stress [24]. This work indicates that AER increase the levels of GAT and SOD, but decreases MDA level in $\mathrm{H}_{2} \mathrm{O}_{2}$ induced $\mathrm{H} 9 \mathrm{c} 2$ cell. These results suggest that $A E R$ inhibits oxidative stress level in $\mathrm{H}_{2} \mathrm{O}_{2}$-induced $\mathrm{H} 9$ c2 cells.
It is reported that inhibition of myocardial apoptosis may be beneficial for treatment and prognosis of various ischemic heart diseases. Caspase family proteins play key roles in regulating apoptosis induced by different stimulus such as oxidative stress, and caspase- 3 is the most important executor in the apoptotic process [25]. Furthermore, Bax is a pro-apoptotic protein in the mitochondria-mediated apoptosis, whereas Bcl-2 is an anti-apoptotic protein [24]. In the present study, AER down-regulated the caspase- 3 and Bax, but up-regulated Bcl-2, indicating that AER suppresses apoptosis in cardiomyocytes.

\section{CONCLUSION}

The findings of the present investigation demonstrate that the acetone extract of $R$. japonicas (AER) alleviates myocardial apoptosis in $\mathrm{H}_{2} \mathrm{O}_{2}$-induced $\mathrm{H} 9 \mathrm{c} 2$ cell. The probable mechanism might be related to the inhibition of oxidative stress and mitochondria-mediated apoptosis. These findings suggest that AER can be further developed for the treatment of myocardial disease.

\section{DECLARATIONS}

\section{Acknowledgement}

This work was supported by National Natural Science Foundation of China (no. 30100069).

\section{Conflict of Interest}

No conflict of interest associated with this work.

\section{Contribution of Authors}

The authors declare that this work was done by the authors named in this article and all liabilities pertaining to claims relating to the content of this article will be borne by them.

\section{Open Access}

This is an Open Access article that uses a funding model which does not charge readers or their institutions for access and distributed under the terms of the Creative Commons Attribution License (http://creativecommons.org/licenses/by 14.0) and the Budapest Open Access Initiative (http://www.budapestopenaccessinitiative.org/rea d), which permit unrestricted use, distribution, and reproduction in any medium, provided the original work is properly credited. 


\section{REFERENCES}

1. Saleh AM, El-Hadidi MN, Arafa RFM. Flavonoids and anthraquinones of some Egyptian Rumex species (Polygonaceae). Biochem System Ecol 1993; 21: $301-$ 303.

2. Vasas A, Orbán-Gyapai O, Hohmann J. The Genus Rumex: Review of traditional uses, phytochemistry and pharmacology. J Ethnopharmacol 2015; 175: 198-228.

3. Giday M, Asfaw Z, Woldu Z. Medicinal plants of the Meinit ethnic group of Ethiopia: An ethnobotanical study. J Ethnopharmacol 2009; 124: 513-521.

4. Demirezer LO. Quantitative determination of some Rumex species with regards of anthraquinone derivatives. Pharmazie 1994; 49: 936-937.

5. Midiwo JO, Rukunga GM. Distribution of anthraquinone pigments in Rumex species of Kenya. Phytochemistry 1985; 24: 1390-1391.

6. Jiang LL, Zhang SW, Xuan LJ. Oxanthrone C-glycosides and epoxynaphthoquinol from the roots of Rumex japonicus. Phytochemistry 2007; 68: 2444-2449.

7. Ke WS, Xiong ZT, Chen SJ, Chen JJ. Effects of copper and mineral nutrition on growth, copper accumulation and mineral element uptake in two Rumex japonicas populations from a copper mine and an uncontaminated field sites. Environmental Exp Bota 2007; 59: 59-67.

8. Jiang LL, Zhang SW, Xuan LJ. Oxanthrone C-glycosides and epoxynaphthoquinol from the roots of Rumex japonicas. Phytochemistry 2007; 68: 2444-2449.

9. Zheng SQ, Chen WS, Tao ZY, Yuan Y, Li B, Zhao CZ. Study on the chemical constituents of Rumex japonicus Houtt. (I). Acad J Sec Mil Med Univ 2000; 442: 21: 910 912.

10. Peng W, Qin RX, Li XL, Zhou H. Botany, phytochemistry, pharmacology, and potential application of Polygonum cuspidatum Sieb.et Zucc.: A review. J Ethnopharmacol 2013; 148: 729-745.

11. Liu B, Bi XD. Effect of emodin on severe acute pancreatitis accompanying myocardial damage and its mechanism. J Chin PLA Postgrad Med Sch 2012; 33: 1299-1302.

12. Ma JK, Jiang YX, Ma HB, Wang XC, Chen ZH, Lei JT. Effect of Rumex japonicus Houtt extracts on hemopoietic system of model mice with thrombocytopenia. J Jilin Univ 2009; 35: 82-86.

13. Xie QC, Yang YP. Anti-proliferative of physcion $8-O-\beta$ glucopyranoside isolated from Rumex japonicas Houtt. on A549 cell lines via inducing apoptosis 5 and cell cycle arrest. BMC Complem Alt Med 2014; 14: 377.

14. Zhang JW, Min DY, Zhou Y, Yang KC, Yu X, Chen DB. Protective effects of lycopene on $\mathrm{H} 2 \mathrm{O} 2$ induced oxidative stress in neonatal rat cardiomyocytes. Chin $\mathrm{J}$ Exp Trad Med Formul 2014; 20: 160-164.

15. Wu LS, Jia M, Chen L, Zhu B, Dong HX, Si JP, Peng W, Han T. Cytotoxic and Antifungal Constituents Isolated from the Metabolites of Endophytic Fungus DO14 from Dendrobium officinale. Molecules 2016; 21: 14, doi: 10.3390/molecules21010014.

16. Reshma PL, Sainu NS, Mathew AK, Raghua KG. Mitochondrial dysfunction in $\mathrm{H} 9 \mathrm{c} 2$ cells during ischemia and amelioration with Tribulus terrestris L. Life Sci 2016; 152: $220-230$.

17. Rezaee MA, Mohammadpour AH, Imenshahidi $M$, Mahmoudi M, Sankian M, Tsarouhas K, Tsakalof A, Tsatsakis AM, Moallem SA. Protective effect of erythropoietin on myocardial apoptosis in rats exposed to carbon monoxide. Life Sci 2016; 148: 118-124.

18. Waldmeier PC, Zimmermann K, Qian T, TintelnotBlomley M, Lemasters JJ. Cyclophilin $D$ as a drug target. Curr Med Chem 2003; 10: 1485-1506.

19. Guo CX, Jiang X, Zeng XJ, Wang HX, Li HH, Du FH, Chen BX. Soluble receptor for advanced glycation endproducts protects against ischemia/reperfusion-induced myocardial apoptosis via regulating the ubiquitin proteasome system. Free Radical Bio Med 2016; 94 : 17-26.

20. Han MM, Wang WF, Liu MY, Li DS, Zhou B, Yu YH, Ren GP. FGF-21 protects H9c2 cardiomyoblasts against hydrogen peroxide induced oxidative stress injury. Acta Phrm Sin 2014; 49: 470-475.

21. Bucciarelli LG, Kaneko M, Ananthakrishnan R, Harja E, Lee LK, Hwang YC, Lerner S. Receptor for advancedglycation endproducts: key modulator of myocardial ischemic injury. Circulation 2006; 113: 1226-1234.

22. Jovanović $S$, Ballantyne $T, D u Q$, Blagojević $M$, Jovanović A. Phenylephrine preconditioning in embryonic heart H9c2 cells is mediated by up-regulation of SUR2B/Kir6.2: A first evidence for functional role of SUR2B in sarcolemmal KATP channels and cardioprotection. Int J Biochem Cell Biol 2016; 70:23-28.

23. Peng W, Hu C, Shu Z, Han T, Qin L, Zheng C. Antitumor activity of tatariside $F$ isolated from roots of Fagopyrum tataricum (L.) Gaertn against H22 hepatocellular carcinoma via up-regulation of p53. Phytomedicine 2015; 22:730-736.

24. Wang $Y$, Han $T$, Xue LM, Han $P$, Zhang $Q Y$, Huang $B K$. Hepatotoxicity of kaurene glycosides from Xanthium strumarium L. fruits in mice. Pharmazie 2011; 66: 445449.

25. Shan H, Yan R, Diao J, Lin L, Wang S, Zhang M, Zhang $R$, Wei J. Involvement of caspases and their upstream regulators in myocardial apoptosis in a rat model of selenium deficiency-induced dilated cardiomyopathy. J Trace Elem Med Biol 2015; 31: 85-91. 